\title{
The Right to Restitution and Compensation in International Law and the Displaced Palestinians
}

\author{
Michael Lynk
}

\begin{abstract}
In any final settlement between Israel and the Palestinians, compensation for the material and moral losses of the Palestinian refugees will be a central feature. The parties have ostensibly agreed that compensation will be paid, but differ significantly on the principles that will determine the global amount of compensation, the valuation of losses, and the method of distribution to the recipients. Compensation for refugees, for victims of human rights violations, and for property loss have becomewell-grounded features in contemporary international law. The author argues that these international law principles should shape the compensation agreement that will settle the conflict, because fairness and transitional justice, rather than unequal bargaining power, will more readily hasten the healing of the many wounds that the Palestinians and Is raelis have endured.
\end{abstract}

\section{Résumé}

Un aspect central de tout accord final entre Israël et les Palestiniens sera la compensation pour les pertes maté rielles et morales subies par les réfugiés palestiniens. En apparence, les deux parties sont d'accord pour que des compensations soient être versées, mais un certain écart les sépare encore sur la question des principes qui serviront à déterminer la somme globale de la compensation, la façon d'évaluer les pertes et les méthodes de distribution aux bénéficiaires. Le droit international contemporain reconnaît pleinement aujourd'hui le droit aux compensations pour les réfugiés, les victimes de violations des droits humains et pour ceux qui ont subi des pertes de biens. L'auteur soutient que ce sont ces mêmes principes de droit international qui devront façonner l'accord de compensation qui clôturera le conflit, car c'est l'équité et la justice transitionnelle plutôt que le pouvoir de marchandage inégal, qui ont le plus de chances de guérir les nombreuses blessures que Palestiniens et I sraéliens ont eu à subir

\section{Introduction}

R eaching a final, durable, and equitable resolution of the Middle East conflict requires the comprehensive settlement of the Palestinian refugee issue. ${ }^{1}$ In its cornerstone pronouncement on the conflict, the United Nations Security Council in 1967 called for the just settlement of the refugee problem. ${ }^{2}$ Israel and the Palestine Liberation Organization acknowledged, in their 1993 Declaration of Principles, that the refugee issueis one of the most intractable problems at the heart of their aspirations for peace, and postponed its resolution until the future initiation of final status negotiations. ${ }^{3}$ Israel has agreed, in its 1994 peace treaty with Jordan, that the persistence of the refugee issue over the past five decades has caused massive human problems in the region, and the settlement of the issue is to be in accordance with international law. ${ }^{4}$ Beyond this, there has been little substantive progress by the parties towards a final settlement of the fate of the Palestinian refugees, and little consensus between them as to the requirements of international law. At the centre of the issue is the national and individual status of the majority of the estimated 7.6 million Palestinians in the world today: the 3.9 million Pal estinian refugees who were displaced, personally or by family lineage, from their homes, properties, and lands by the 1947-49 and 1967 Middle East wars. The irresolution 
of their fate perpetuates the largest, longest-running and most destabilizing refugee problem in the world today.

Contemporary legal, political, and diplomatic analyses of the Palestinian refugee issue have focused on three principal components: repatriation, resettlement, and compensation. In current settlement proposals, these three components are intimately interlinked, but they are each capable and deserving of stand-al oneanalysis. Repatriation focuses on the generally accepted right in international law of refugees to choose whether to return to their homeland and their homes following the cessation of conflict or persecution. ${ }^{5}$ Palestinians claim their capacity to exercise this right of return extends to Israel as well as to a future state of Pal estine, ${ }^{6}$ while the most liberal position articulated by official and semi-official Israeli spokespersons have argued that any more than a very modest number of refugees returning to their ancestral homes within its borders would threaten its existential character as a Jewish state. ${ }^{7}$ Resettle ment is the strongly maintained Israeli solution, which would see all, or almost all, of the estimated 3.9 million registered Palestinians refugees required to accept permanent civil status of some form in their present homes in Syria, Lebanon, and Jordan, return to a truncated Palestinian state, or accept relocation elsewhere. ${ }^{8}$ Palestinians re sist this option, arguing that it would abolish their legal right to return and negate their decades of suffering in exile. ${ }^{9}$

The third issue, compensation, focuses on the individual and collective claims of the Palestinian refugees and the displaced for the restitution of, and/or indemnification for, their lost homes and properties in present-day Israel, as well as monetary damages for related losses. Both sides agree that compensation should be part of a final peace agree ment, but for quite different reasons which would lead to quite different results. I srael prefers a global collectivefund that would be primarily used for refugee resettlement elsewhere and financed largely by international donors. Its contributions would be made ex-gratis, without assuming any official liability. ${ }^{10} \mathrm{On}$ the other hand, the Palestinians advance the compensation issue as a right recognized in international law that would obligate Israel to return, or pay for, the refugee properties expropriated or destroyed in 1948 and afterwards. As well, they argue that Israel must pay damages for pain and suffering, and for its use of Palestinian properties over the past five decades. ${ }^{11}$

These differences on compensation are significant. The gap between the parties goes to a number of issues, including: (i) the legal basis for compensation; (ii) the number of potential claimants; (iii) the range of compensation categories; (iv) methods of calculation; (v) whether restitution forms part of the compensation issue; (vi) whether the compensation should be awarded collectively or individually; and (vii) the status of related issues, such as the compensation claims of (a) the Arab countries that have hosted the Palestinian refugees for five decades, and (b) the Arab Jews who left behind property in their homecountries such as Iraq and Egypt in the 1950s. The differences on compensation have never been publicly expressed in dollar figures by I srael or the Palestine Liberation Organization, but recent assessments by scholars and researchers range from $\$ 5-10$ billion (US) by Shlomo Gazit, ${ }^{12}$ to $\$ 15-20$ billion in a $\mathrm{H}$ arvard refugee project led by Joseph Alpher and Khalil Shikaki, ${ }^{13}$ to $\$ 271$ billion by Atif Kubursi. ${ }^{14}$

This article focuses on the issue of compensation, which for these purposes includes restitution. ${ }^{15}$ Whether thePalestinian refugee issue is eventually resolved through repatriation or resettlement, or some combination of both, compensation will inevitably be a significant feature of the final agreement. However, if this final agreement is to be durable, it must reflect the fair aspirations of both parties. As such, it will have to be anchored in the principles of international law, and not simply reflect thestarkly unequal bargaining strengths between Israel and the Palestinians. Indeed, if compensation and restitution are to play a forwardlooking roletowards healing the transparent wounds of the decades-long conflict, and building the foundation for a prosperous and secure future in the region, then the available rules found in international law are both the principled and the most constructive road to follow. ${ }^{16}$

\section{The Dimensions of the Issue}

A. An H istorical Précis to 1948

On 29 November 1947, with the British M andate in Palestine collapsing, the United Nations General Assembly passed Resolution 181(II). ${ }^{17}$ It recommended the termination of the Mandate, the partition of Palestine into independent Arab and Jewish states, and a special international status for Jerusalem. Following months of civil violence, the State of I srael declared its independence on 14 M ay 1948, and a larger war involving the neighbouring A rab countries ensued. This larger war alternated between periods of intense conflict and unstable truces until the signing of the Rhodes armistice agreements in 1949. At the conclusion of the war, I srael was victorious and its land sizehad expanded from the 54 per cent of $M$ andate Palestine allocated to the Jewish state by UNGA resolution 181(II) to 78 per cent of the territory.

Between December 1947 and September 1949, approximately 725,000 Palestinians - more than half of the Arab population of Palestine - were driven from, or fled, their homes in that part of Pal estine that became Israel..$^{18}$ They sought refuge primarily in the neighbouring Arab coun- 
tries, including the West Bank of the Jordan River (occupied by Jordan after 1949), Jordan, Syria, Lebanon, and the Gaza Strip (administered by Egypt after 1949). The first UN M ediator for Palestine $\mathrm{e}^{19}$ and modern historians of the period ${ }^{20}$ have observed that the Palestinians fled for the same mixture of reasons that have caused most mass population displacements in the twentieth century: forced expulsions, a widespread fear of harm from advancing armies, and panic after credible reports of civilian massacres by Israeli militias.

In his September 1948 progress report to the UN Secretary-General, the M ediator for Palestine, Count Folke Bernadotte, urged the United Nations to affirm that the Palestinian refugees had the right to return to their homes at the earliest practicable date: "It is, however, undeniable that no settlement can be just and complete if recognition is not accorded to the right of the Arab refugee to return to the home from which hehas been dislodged by the hazards and strategy of the armed conflict between Arabs and Jews in Palestine." 21 In his listing of the basic premises for an equitable resolution of the conflict, Count Bernadotte recommended that those refugees choosing not to return should be paid "adequate compensation" for their properties. $^{22}$ (This echoed the United Nations' stipulation in Re solution 181 (II) the year before that "full compensation" was to be paid for the expropriation of any Arab land by the J ewish state. $)^{23} \mathrm{M}$ oreover, he added in his report that I srael bore the responsibility to indemnify those owners whose property had been wantonly destroyed during the conflict, with no qualification as to whether they returned from their exile or not. ${ }^{24}$ The day after delivering his report, Count Bernadotteand an ai dewereassassinated by theStern Gang, an extremist Jewish militia.

The United Nations General Assembly adopted the thrust of the Bernadotte report in December 1948 in UNGA Resolution 194. ${ }^{25}$ In Paragraph 11, the General Assembly endorsed the report's recommendations on the right of return and compensation:

The General Assembly, having considered further the situation in Palestine... [r] esolves that the refugees wishing to return to their homes and live at peace with their neighbours should be permitted to do so at the earliest practicable date, and that compensation should bepaid for the property of thosechoosing not to return and for loss of or damageto property which, under principles of international law or in equity, should be made good by the Governments or authorities responsible.

In its resolution, the General Assembly spoke to four primary features of the compensation question, all of which flowed directly from the Bernadotte report. First, it stated that those refugees willing to live at peace with their neigh- bours were entitled to the restitution of their homes at the earliest practicable time. Second, those refugees not returning home should beentitled to compensation for their lost property. Third, those refugees who do return home and find their properties damaged or destroyed should be compensated for their losses. And fourth, it explicitly grounded its direction that the refugees were entitled to repatriation, restitution, and compensation based upon the principles of international law and equity. Ironically, whilethesefeatures of Resolution 194 would significantly influence the rights in international law that refugees and victims of human rights abuses elsewhere could claim in the years to come, these entitlements have been largely unavailable for the intended recipients.

\section{B. After 1948}

Thehomes, lands, and properties left behind by theflight of the Pal estinians between 1947 and 49 were substantial. The United Nations Conciliation Commission for Palestine (created by Resolution 194 to resolvethe outstanding issues between Israel, the Palestinians, and the neighbouring Arab countries) ${ }^{26}$ estimated in 1951 that almost 80 per cent of Israel's total area of 20,850 square kilometres represented abandoned Arab lands, although only about 28 per cent of that land was cultivable. ${ }^{27}$ Approximately 400 Arab villages and towns, representing most of the Palestinian communities in the territory assigned to, or captured by Israel, were occupied and depopulated during the war. ${ }^{28}$ The transfer of wealth to Israel in the form of Palestinian lands, homes, assets, and property was crucial to the new state's ability to survive and develop in its formative years. ${ }^{29}$ Between 1948 and 1953, 350 of the 370 new Jewish settlements created in Israel were on former Arab property. Don Peretz has estimated that, by 1954, more than one-third of the Israeli Jewish population were living on former Arab lands, and an additional 250,000 Israeli Jews, including one third of the new immigrants, lived in abandoned Arab urban property. ${ }^{30}$ In the countryside, where most Pal estinians had lived prior to 1948, enormoustracts of citrus, olive, and other cultivable properties were expropriated by Israel and turned over to Jewish agricultural settlements. The importance of these agricultural lands was critical to the fledging Israeli economy: to cite one example, exports of citrus products from expropriated Arab groves provided nearly 10 per cent of Israel's foreign currency earnings in 1951.31

Israel subsequently legalized the land and property expropriations through legislation that vested broad powers in the state-appointed Custodian of Absentee Property, who was to hold all of the abandoned properties of the "absentees" in trust. ${ }^{32}$ An absentee was defined expansively as any Arab in Palestine who left his or her home after 29 
November 1947, and the burden of proof that a claimant was not an absenteefell on the former owner. ${ }^{33}$ Eventually, much of the expropriated Palestinian lands and properties held by the Custodian were transferred via a purchase agree ment to an I sraeli statedevelopment authority, which allowed thel sraeli government to maintain that these properties were acquired legally (i.e., through payment), even though the Palestinians owners never received any money. ${ }^{34}$ This authority, in turn, turned these properties over to the Jewish National Fund, whose charter explicitly prohibited it from selling, leasing, or returning the lands to non-Jews. These steps had the effect of completely severing the proprietary link between the absentees and their lands. ${ }^{35} \mathrm{Although} \mathrm{Pa}-$ lestinian refugees living in exile and even those displaced within Israel sought to have their properties returned to them, very few ever succeeded. ${ }^{36}$ By the early 1950 s, Israel had so significantly transformed the emptied Palestinian properties through irreversible steps - such as the levelling of villages, the settlement of Jewish immigrants into abandoned homes, and the establishment of kibbutzim and moshavim (Jewish agricultural settlements) on cultivated Arab farmsthat there was increasingly little of the lands and homes of the displaced Palestinians which remained in its original state. ${ }^{37}$

During these early years, Israel was prepared to address the question of compensation for the abandoned Palestinian properties, but tied its commitment to a number of pre-conditions that amounted to deal-breakers. ${ }^{38}$ At the centre of its position was its insistence that it would not accept the return of the refugees, and that there would be no restitution of abandoned Palestinian properties. After 1950, the Israeli authorities developed the argument that the Jews who left behind their properties in I raq and other $M$ iddle East countries when they emigrated to Israel constituted a population exchange, which settled any compensation or restitution obligations which it might have owed to the displaced Palestinians. ${ }^{39}$ The position of the Arab countries on compensation was starkly different. ${ }^{40} \mathrm{At}$ the heart of their argument was the fulfilment of Resolution 194 and the right to repatriate. Only after the free choice of refugees as to whether to return was exercised, the Arab states maintained, could the subsequent issue of compensation be determined and implemented. There should be no linkage with the compensation claims of the Arab Jews, since their claims had no direct nexus with the Pal estinians. Thus, while both sides accepted the premise of compensation, no progress was made towards a settlement because of the larger, intractable issue of repatriation. ${ }^{41} \mathrm{~W}$ ith no agree ment, the unresolved fate of the displaced Palestinians was left to fester as an open political sore that would spark four more wars, two sustained popular uprisings, and chronic regional instability over the next five decades. ${ }^{42}$

\section{The Right to Compensation and Restitution in International Law}

A. Introduction

Compensation for refugees and displaced persons, and for victims of the abuse of internationally recognized human rights, has evolved into the status of a right in international law. It has acquired that status because it sati sfies the criteria that are commonly accepted as the formal sources of international law. ${ }^{43} \mathrm{Applying}$ these criteria, the obligation to pay compensation to refugees and displaced persons is evident in the requirements of regional treaties, conventions, and agreements; in the domestic and international practice of states; in the rulings of international judicial bodies; in the consensus among scholars of international law; and in the repeated pronouncements of the international community as expressed in the relevant bodies and organs of the U nited Nations. While the modern body of rights for refugees and displaced persons emerged only after the Second World $W$ ar, theantecedents of the right to compensation and restitution are evident even in the nascent years of international law.

The policy justifications for articulating the principle of compensation and restitution as a right for refugees and displaced persons in international law are at least five-fold. First, since modern international law forbids the mass expulsion of civilian populations even during wars and civil conflict ${ }^{44}$ and prohibits the domestic conditions of persecution that create large-scale refugee displacements, ${ }^{45} \mathrm{com}$ pensation is regarded as a potent tool to deter potential states of origin from domestic actions that would generate refugees. ${ }^{46}$ Second, as a principle of equity, countries should not benefit from proceeds reaped through violating the human rights of minorities or the nationals of other countries. ${ }^{47} \mathrm{Third}$, compensation and restitution serve to repair some of the individual and/or group dignity lost by the refugee through the violation of her or his human rights by mass displacement. ${ }^{48}$ Fourth, where compensation is assessed and collected against a refugee-generating state, both the international community and the individual refugees will have their financial burdens reduced. This would be a particularly important benefit for refugees, whose movable and immovable property they lost through the conflict or persecution they fled from invariably represents the sum total of their meagre personal wealth. ${ }^{49} \mathrm{And}$ fifth, the compensation principlemay assist with the reconciliation of the parties or groups to the conflict that sparked the mass population displacement, as part of a broader range of restorative remedies, such as a frank apology, the revel ation of the truth, substantial reforms to political and social institutions, public educational campaigns to transform attitudes, and substantial changes to employment patterns..$^{50}$ 


\section{B. The O rigins of the Right to Compensation in International Law}

Prior to the emergence of modern human rights, humanitarian, and refugee law in the immediate aftermath of the Second World War, compensation and restitution for displaced persons had al ready been a regular practice in international treaties and state practice (although not in a consistent manner nor with theagreed-upon compensation obligations always being honoured). For example, in the aftermath of the American War of Independence, 60,000 American colonialists loyal to the British crown fled their homes and properties in the newly independent United States. In the 1794 Treaty of Amity, Commerce and N avigation (the "Jay Treaty") ${ }^{51}$ between Great Britain and the U nited States, the Americans agreed that the Loyalists could claim either the restitution of their properties or compensation for their property and commercial losses. ${ }^{52}$ H owever, the subsequent deterioration of political relations between the two countries resulted in theAmerican abdication of any responsibility to pay the Loyalist claims.

Similar examples of early European and international treaties and laws that recognized compensation and/or restitution claims for displaced civilians include the 1648 Treaty of W estphalia that ended the Thirty Y ears W ar $^{53}$ the 1678 T reaty of N immegeun between Spain and France that ended the war over the Spanish N etherlands; ${ }^{54}$ and the 1839 Treaty of London that guaranteed the independence and neutrality of Belgium, ${ }^{55}$ among others. ${ }^{56}$ Even treaties that legitimized mass displacement of civilians and population exchanges (actions that arenow prohibited by international $\left(a w^{57}\right)$ - such as the 1920 Treaty of N euilly between Greece and Bulgaria, ${ }^{58}$ and the 1923 Treaty of Lausanne between Greece and Turkey ${ }^{59}$ - contained provisions to compensate civilians who lost properties.

The modern basis for compensation and restitution in international law has been decisively shaped by the seminal 1928 ruling of the Permanent Court of International J ustice in Chorzow Factory. ${ }^{60}$ In the aftermath of World W ar One, the Polish government expropriated a German-owned factory on Polish territory, and the German government sought reparations on behalf of the owners. In its lead ruling on the merits, the World Court stated that state responsibility applies in the case of an act or omission in violation of an international legal obligation:

It is a principle of international law, and even a general conception of law, that any breach of an engagement invokes an obligation to make reparation. [R] eparation is the indispensable complement of a failure to apply a convention, and there is no necessity for this to be stated in the convention itself. ${ }^{61}$
Regarding damages, the Court endorsed the principle of restitution first, and full compensation for the property owners where restitution was unobtainable. In addition, it stated that awards for other damages not covered by restitution and compensation were also available:

The essential principle contained in the actual notion of an illegal act - a principle which seems to be established by international practice and in particular by the decisions of arbitral tribunals - is that reparation must, as far as possible, wipe out all the consequences of the illegal act and re-establish the situation which would, in all probability, have existed if the act had not been committed. Restitution in kind, or, if this is not possible, payment of a sum corresponding to the value which a restitution in kind would bear; theaward, if need be, of damages sustained which would not be covered by restitution in kind or payment in place of it - such are the principles which should serve to determine the amount of compensation due for an act contrary to international law. ${ }^{62}$

Although Chorzow Factory was decided as a commercial property action in private international law, its articulation of the principles on compensation have since been widely endorsed in various public international law decisions. These endorsements include leading judgments on damages for injuries to U nited N ations personnel ${ }^{63}$ and reparations for human rights violations, ${ }^{64}$ as well as by a seminal United Nations study on compensation for human rights violations. ${ }^{65}$

\section{Resolution 194 and the Articulation of the Right to Compensation}

United Nations General Assembly Resolution 194, which established the availability of return, compensation, and restitution for the Palestinian refugees, was the world community's first affirmation of these principles in the context of a displaced population. Resolution 194 is commonly cited by refugeelaw scholars as a primary international law source for the right of refugees and displaced persons anywhere in the world to compensation and restitution. ${ }^{66} \mathrm{~T}$ wo particular features of Resolution 194 embed it with an international law importance that distinguishes it from the limited legal scope of an ordinary General Assembly resolution.

First, Resolution 194 explicitly states that the repatriation, compensation and restitution of the refugees should be made according to "... principles of international law or in equity." Luke Lee argues that, by deliberately choosing this particular drafting, the General Assembly clearly signalled that it was restating pre-existing law on theprinciple of compensating wrongs in international law, rather than simply establishing a new legal obligation. ${ }^{67}$ As such, the 
resolution moves beyond the recommendatory and political character of most General Assembly resolutions and acquires a legal, binding nature. Its binding effect arises not from the resolution itself, but from the declared law, which is then obligatory upon all states, whether they voted in favour of the resolution or not. ${ }^{68}$

Second, the resolution has been repeatedly affirmed by the General Assembly. Since 1948, Resolution 194 has been reaffirmed or referred to, by near unanimous majorities, at least 140 times. ${ }^{69}$ For instance, UNGA Resolution 53/51, voted on 3 December 1998, expressly cited Resolution 194 when endorsing the entitlement of Palestinian refugees "to their property and to the income derived therefrom, in conformity with the principles of justice and equity." 70 Resolution 53/51, like its many predecessor resolutions, was passed by an overwhelming majority, in this case 156 member countries in favour and only two (I srael and the United States) in opposition. International law scholars have stated that, in specific circumstances, the repeated affirmation of a resolution by unanimous or overwhelming majorities of the General Assembly endows it with an acquired legal character, particularly when it reflects the parallel development of state practice on the issue. ${ }^{71}$ Leading judgments of theW orld Court haveendorsed this approach. ${ }^{72}$

\section{General Principles of Domestic Law}

A leading sourcefor international law arethegeneral principles of domestic law widely accepted by the developed legal systems, insofar as they apply to international rights and obligations.73 The principles of compensation and restitution have been cornerstone features of most domestic legal systems for centuries, ${ }^{74}$ and constitute the primary remedial response to repair proven damages and instances of unjustenrichment. For example, theEnglish common law courts havelong applied the principle; in Fibrosa Spolka Akcyjna v. Fairbairn Lawson Combe Barbour Ltd., Lord W right stated in 1943 that:

It is clear that any civilized system of law is bound to provide remedies for cases of what has been called unjust enrichment or unjust benefit, that is to prevent a man from retaining the money of or some benefit derived from another which it is against conscience that he should keep. ${ }^{75}$

Similarly, the American Law Institute, in its seminal restatement of the domestic law on restitution, has established that: "A person who has been unjustly enriched at the expense of another is required to make restitution to that other."76

\section{E. International Treaties and Conventions}

Through treaties and conventions, international law has accepted the cornerstone principle that a state which has violated a legal obligation is required to end the violation and to make reparation, including restitution and compensation for loss and injury in the appropriate circumstances. ${ }^{77}$ These international instruments also stipulate that those whose human rights have been breached are to have access to meaningful remedies. Article 8 of the U niversal D eclaration of Human Rights states that every individual is entitled to an "effective remedy," 78 a requirement that is repeated in the International Covenant on Civil and Political Rights ${ }^{79}$ and the Declaration on the Elimination of all Forms of Racial Discrimination. ${ }^{80}$ Other human rights instruments are even more specific: the American Convention on Human Rights refers to a "right to be compensated in accordance with the law" 81 and provides that "no one shall be deprived of his property except upon payment of just compensation," 82 while the African Charter on Human and Peoples' Rights establishes the "right to an adequate compensation." ${ }^{83}$ The International Covenant on Civil and Political Rights ${ }^{84}$ and the European Convention on Human Rights ${ }^{85}$ both refer to the "enforceable right to compensation." The 1998 Treaty of Rome ${ }^{86}$ which established the International Criminal Court, has directed the new court to establish principles of restitution, compensation, and rehabilitation for victims of international war crimes. Other international treaties and conventions contain similar remedial requirements. ${ }^{87}$

Theo van Boven, a Special Rapporteur for the United Nations Commission on H uman Rights, issued a comprehensive final report in 1993 on international law remedies arising from the violation of human rights norms. ${ }^{88} \mathrm{After}$ reviewing a number of international treaties and conventions, he stated: "the principal right [that human rights] victims are entitled to under international law is the right to effective remedies and just reparations." 89 In his conclusion, the Special Rapporteur said: "it is... an imperative norm of justicethat... the rights of the victims besustained to the fullest possible extent." 90 These remedies included restitution, compensation, rehabilitation and guarantees of non-repetition, ${ }^{91}$ and would be claimed against the state perpetrating the violations. Among the human rights and fundamental freedoms - whose gross violation would trigger a claim for remedies under international law - that van Boven listed were "deportation or forcible transfer of population". ${ }^{92}$ The Special Rapporteur also maintained that international law contains no statute of limitations for claims regarding human rights reparations. ${ }^{93}$

\section{F. Contemporary International Law Rulings}

Decisions by international legal courts and tribunals, particularly since the 1980s, have affirmed that compensation and restitution are available remedies for displaced persons and victims of human rights abuses. U sing both the $1928 \mathrm{~W}$ orld 
Court decision in Chorzow Factory and international human rights treaties as the legal foundation for the principle, such international judicial bodies as the Inter-American Court of H uman Rights and theEuropean Court of H uman Rights have ruled that violations of international obligations which result in harm create an obligation to compensatefor and repair the damages. The Inter-American Court has stated that:

It is a principle of international law, which jurisprudence has considered "even a general concept of law", that every violation of an international obligation which results in harm creates a duty to make adequatereparation. Compensation, on theother hand, is the most usual way of doing it. ${ }^{94}$

In 1989, the Inter-American Court ruled in VelasquezRodriguez v. Honduras, ${ }^{95}$ a case under the American Convention on $\mathrm{H}$ uman Rights ${ }^{96}$ involving state responsibility for the disappearance of H onduran citizens, that international law requires restitution of the status quo ante where possible, and compensation where it is not possible. ${ }^{97}$ After finding $\mathrm{H}$ onduras liable for human rights violations, the Court held that the claimants were entitled to a broad range of compensation headings under international law, as per the "fair compensation" criteria in Article 63(1) of the Convention. These headings included damages for lost salaries, based on probable futureearnings, and moral damages, based upon theemotional harm suffered by thefamilies of the victims. The Court emphasized that the "fair compensation" criteria must be applied in "sufficiently broad termsin order to compensate, to the extent possible, for the loss suffered." ${ }^{98}$ These compensation principles have been regularly applied by the Inter-American Court in subsequent decisions. ${ }^{99}$

In a similar manner, the European Court of Human Rights has ruled under the European Convention on $\mathrm{H}$ uman Rights ${ }^{100}$ that the deprivation of property and human rights obligates the offending state to provide restitution and compensation for the claimant. In Loizidou v. Turkey, ${ }^{101}$ a Greek Cypriot national with property holdings in the northern part of Cyprus occupied by Turkey since 1974 complained that she was prevented from returning to her lands and peacefully enjoying them. The Court found that Turkey was responsible, as the occupying power, for breaching the Convention, and rejected its arguments that its stated need to rehouse displaced Turkish Cypriot refugees justified the negation of Ms. Loizidou's property rights. At the remedial stage, ${ }^{102}$ the European Court ruled that the claimant was still the legal owner of the property, and entitled to reclaim her landsat any time. Asreparations, it awarded compensation for ground rent (based on the market value earnings that could have been realized but for the occupation), moral damages for the loss of property enjoyment, and costs and interest.

More recently, the European Commission of Human Rights issued a 1999 report ${ }^{103}$ on Cyprus, where it applied the principles in Loizidou regarding the claims of other displaced Greek Cypriots to property restitution and compensation. The Commission unanimously found that Turkey remained in continuing breach of the European Convention on $\mathrm{H}$ uman Rights because of its ongoing refusal to allow Greek Cypriots to return to their homes in northern Cyprus. It also ruled that Turkey's refusal to pay compensation for its interference with the claimants' property rights breached the Convention. Turkey's defence that property succession legislation enacted by the Turkish Republic of N orth Cyprus invalidated the property claims was rejected by the Commission, as was its argument that property restitution and compensation should await a future global settlement of the Cyprus issue. ${ }^{104}$

\section{G. Contemporary State and International Practice}

Recent state and international practice have provided rich examples of restitution and compensation for violations of property and human rights. Many modern treaties and agreements that ended international or national conflicts have included these principles in the final settlement. Similarly, most countries in Eastern and Central Europe in the 1990s have offered restitution and compensation for those who lost properties or suffered human rights abuses under fascism or communism. As well, there are a number of contemporary domestic examples where these remedial principles have been applied as a restorative step to address a troubled history between majority and minority populations.

The template for the modern international obligation to compensatefor unilateral property confiscations and wide scale human rights abuses has been the post-war German and European reparations for Jewish and other victims of N azi persecution. ${ }^{105}$ Following the 1952 Luxembourg Agreement ${ }^{106}$ between the Federal Republic of Germany, I srael, and the Conference on Jewish M aterial Claims against Germany, the West German government enacted a series of laws to provide compensation for gross violations of human rights (such as loss of life, loss of health, forced labour, deportation, imprisonment, maltreatment, and degradation) and for property losses (including immovable and moveable property, capital, income, securities, mortgages, pensions, copyright and patents) for victims or their heirs. ${ }^{107}$ These compensation payments have amounted to DM 100 billion up to the year 2000, payable to Holocaust survivors, both individually and through theState of I srael. The range of compensable claims for $\mathrm{N}$ azi victims has been 
steadily widened through the decades to include Swiss bank accounts, European insurance policies, looted works of art, and slave labour. ${ }^{108}$ Other European countries, such as Austria, Norway, Denmark, and the N etherlands have also undertaken to offer compensation to Jewish and other victims of Nazism. ${ }^{109}$ And with the fall of communism in Eastern Europe, procedures have been created in a number of countries-including H ungary, Poland, Slovakia, and the Czech Republic - to restore property confiscated either by fascist or communist regimes to Jewish and other dispossessed owners. ${ }^{110}$ After German reunification in 1990, the German parliament enacted legislation to restore confiscated Jewish properties in the former East Germany to their original owners or heirs, and to award the proceeds from the sales of communal and unclaimed Jewish property to the Jewish Claims Conference in order to aid needy Holocaust survivors worldwide. ${ }^{111}$

In Bosnia, a centrepiece of the 1995 Dayton Peace Agree ment ${ }^{112}$ that brought the first war in the former Yugoslavia to an uneasy end was the provision that all refugees and displaced persons would have theright to return home and have their properties restored to them. Alternatively, compensation for properties was available for those that either could not, or did not wish to, return to them. ${ }^{113}$ TheD ayton Agreement established a Commission for Displaced Persons and Refugees, later renamed the Commission for Real Property Claims of Displaced Persons and Refugees, to adjudicate real property claims, including the return of the confiscated property, or, in lieu of return, the awarding of "just compensation." ${ }^{114}$ Compensation may be awarded in the form of money or in the form of a bond for the future purchase of real property elsewhere in Bosnia. For a variety of international and inter- ethnic reasons, the D ayton compensation provisions have been only implemented in a piecemeal fashion, as the legal structures to adjudicate the claims await the realization of political will. ${ }^{115}$ In a related legal process, an international human rights chamber in Sarajevo has declared that displaced property owners in Bosnia are entitled to be compensated for the unlawful eviction from their residence, through declaratory relief and moral damages, based upon the European Convention on Human Rights. ${ }^{116}$

As part of the recent resolution of other international and domestic conflicts, compensation and restitution have been integral parts of the settlement process. In the aftermath of the Second Gulf War in 1990-91, the United Nations established a compensation commission to process claims and pay out compensation for property, personal, and moral losses resulting from the Iraqi invasion and occupation of Kuwait. ${ }^{117}$ The Iraq-Kuwait compensation experience built upon the lessons of the Iran-U nited States
Claims Tribunal, created in 1981 to adjudicate the American claims for property and material losses following the 1979 I slamic revolution in I ran. ${ }^{118}$ In Guatemala, the agreements in the early 1990s that brought an end to the fourdecades-old civil war stipulated property restitution and compensation to land ownerswho fled thecountry during the armed conflict. ${ }^{119}$ Domestically, compensation has played a role in repairing the civil rights violations of JapaneseAmericans ${ }^{120}$ and Japanese-C anadians ${ }^{121}$ for their arbitrary detention and property confiscation during the Second World War. Similarly, the tools of compensation and property restoration have shaped the modern attempts of the U nited States, ${ }^{122}$ Canadian, ${ }^{123}$ Australian, ${ }^{124}$ and N ew Zealand ${ }^{125}$ governments to restitute their aboriginal peoplesfor the centuries of land alienation and social harm that these states inflicted upon them. After the fall of oppressive military dictatorships in Chile, Argentina, U ruguay, and Uganda, thenew democratic governmentsenacted legislation that offered compensation and, where possible, restitution for victims of human rights abuses and property losses by the previous regimes. ${ }^{126}$

\section{Restitution, Compensation and the Palestinians}

International law authoritatively establishes that restitution and compensation areavailableremediesfor thosewho have been displaced or turned into refugees through acts contrary to international treaties and conventions, for those who have suffered gross violations of their internationally recognized human rights, and for those who havelost homes or property through the breach of internationally established standards. In the case of the M iddle East conflict, the Palestinians who became refugees, who lost properties, or who suffered other legally recognized damages as a consequence of the various upheavals in the region - and particularly the 1947-49 and 1967 wars - also have an established legal grounding for restitution and compensation in the substantial body of U nited $\mathrm{N}$ ations resolutions that specifically refer to their claims. Indeed, it would be difficult to find another community of disadvantaged people for whom the modern principles of international law - especially in the fields of human rights and refugeelaw - so clearly buttress their claim either to havetheir properties restored to them or to receive appropriate compensation for their losses.

Establishing the entitlement to compensation and restitution as a right in international law is one matter. Articulating the detail of substance and procedure that must invariably accompany the realization of this right is quite another. As a body of principles, international law has become a mature legal system, deserving of the considerable respect it enjoys in the modern world because of its 
impressive assembly of the values that the international community has declared it wishes to live by. But, as a guide to the efficacious application of these principles, the practice of international law has been considerably less sophisticated. Its application of these principles has been an inchoate array of uneven experiences, shaped by two primary factors: (i) the poverty of political will to implement theseprinciples in a manner consistent with theinternational rule of law; and (ii) the wide variety and real differences among the many contemporary experiences where the application on international law has been attempted. D eveloping the practical rules to implement an international right - such as the entitlement to restitution and compensation - has, in many cases, been an original creation, an ad hoc arrangement. Yet, increasingly, this need not be so. The accumulation of international experience has reached the point where sufficient precedents and rules exist, particularly on restitution and compensation, to productively and equitably craft their implementation in any contemporary situation.

The Pal estinian claims for restitution and compensation areneither exceptional nor insurmountable. Theonly substantive obstacleis political will. W hile the circumstances of the Palestinians present some particular challenges - which is unsurprising, given their massive displacement, their enormous personal, property, and moral losses, the subsequent transformation of their homes and lands, thearray of international political actors involved, and the extraordinary length of time involved - recent international and domestic practice from elsewherepoints to applicable rules that can be successfully adapted to untie this Gordian knot. In anticipation that the negotiations between thelsraeli and Palestinian representatives will eventually turn to theissues of compensation and restitution, five aspects of the issue stand out that will form a significant feature of the parties' final settlement of the rights of the Palestinians. W hilethese five aspects are all worthy of an extended discussion, they can, for the purposes of this essay, only bereviewed briefly. ${ }^{127}$

\section{A. Return and Compensation}

M odern international law, beginning with the proclamation of the Universal Declaration of H uman Rights in December 1948, has insisted that refugees and displaced persons, as well as their descendants, have the right to return to their homes, if that is their freely determined choice. ${ }^{128}$ The $\mathrm{Hu}$ man Rights Committee, the U nited $\mathrm{N}$ ations body responsible for interpreting the International Covenant on Civil and Political Rights, stated in 1999 that "there are few, if any, circumstances in which deprivation of the right to enter one's own country could be reasonable."129 The right to return survives even when sovereignty over the lands from where the displaced had fled is contested or has changed hands. Those unable to return to a former home because it is occupied by an innocent third party or has been destroyed are entitled to choose return to the vicinity or to receive compensation. However, international law holds that compensation is not a substitute for the right to return to one's home. ${ }^{130}$ To that end, the ensuing discussion on restitution and compensation is to be seen in the context of remedies adjacent to the right to return, not in place of it.

\section{B. Types of Compensation}

According to international law and practice, the Pal estinians eligible for restitution and compensation have a range of remedies available to them, including: (i) the restitution of their confiscated movable and immovable properties; (ii) compensation for the damages to their restituted properties; (iii) compensation for the income derived from the use of their restituted properties; (iv) compensation for those refugees and displaced who choose not to return; and (v) damages for a spectrum of non-material losses, including lost earnings and opportunities, and social and moral damages. In addition, collective restitution claims are available for: (i) expropriated religious, educational, communal, and publiclands; and (ii) theuseand depletion of natural resources, such as water, minerals, and forests. Technically, the accomplishment of these remedies within the regional context is feasible, because the extensive historical documentation on property and ownership in Palestinehas been largely preserved. The land records assembled by the British M andate authority, the United N ations CCP, the Israeli Custodian of Absentees' Property, and the Israeli LandsAuthority, as well as the personal records of thefamilies of the displaced and refugees, would make compensation an easier technical task in comparison to the successful claims achieved in recent years by victims of European fascism and by the aboriginal nations in North America, Australia, and $\mathrm{New}$ Zealand.

Politically, the types of compensation awarded would depend on the prior determination of how many of the displaced Palestinians would achieve the right to return to Israel and have their original properties restored to them. Palestinian researchers have maintained that thetotal compensation pricetag would be significantly reduced if a greater number of displaced and refugees were able to return to their homes inside Israel. ${ }^{131} \mathrm{H}$ owever, discussions within the status quo framework indicate that a final settlement on the Palestinian refugee issue will consist largely of compensation in exchange for the negation of the large-scale right to return. The leading example is the 1995 Beilin-Abu $M$ azan agreement, ${ }^{132}$ where a future I sraeli justice minister and a senior advisor to the Palestinian Authority developed 
an unofficial, but influential, template for a final status settlement. It accepted the right of the displaced Palestinians to compensation and rehabilitation for their material and moral losses, while excluding any significant return of, or to, their properties within Israel. The issue of restitution was raised at the January 2001 final status talks in Taba, where the Israelis rejected any return of refugee property. $133 \mathrm{H}$ ow the parties to the final status negotiations will square any agreement that dissolves the right of Palestinian refugees to return to their original lands with the cornerstone principle in international refugee and human rights law that refugees have a right to freely choose repatriation back to their homeland will be a closely observed matter.

\section{Valuation of Losses}

International law requires that compensation for internationally recognized losses should, as much as remedies can, placetheclaimantsback in theposition that they would have been in, had the breach of the legal right not occurred. Beyond that, it has not spoken with particular clarity regarding the precise formula to use, employing at different times the terms "full," "just," "fair," and "adequate" to describe the compensation required. While "full compensation" is an appropriate yardstick in international claims of small and medium size, large-scale claims - because their size creates problems of efficiency, fairness, and cost - have tended towards less-than-global "attai nable justice" standards. Indeed, the larger and more complex the potential claim, the more likely it has been that the final compensation arrangement will be a judicious mixture of political feasibility (i.e., available financial resources and domestic public reaction) and the requirements of justice (i.e., international legal obligations, international pressure, and the cost of ongoing dissent by the aggrieved party). "Attainable justice," while necessarily falling short of "full compensation," is an acceptable and appropriate standard in large-scale international claims where: (i) the aggrieved party freely agrees to the settlement or it is the result of a legal process that the aggrieved party has freely agreed to adhere to; (ii) the compensation addresses all of the recognized losses; (iii) internationally accepted means of valuation for the losses are employed; and (iv) the party responsible for the compensation of the losses undertakes a guarantee of non-repetition. H owever, with whatever valuation standard is chosen, international law requires that it is to be given a broad application, so that the restorative purposes of human rights remedies - which include justice, equity, acknowledgement of responsibility, deterrence, reconciliation, and social harmony - are achieved.

\section{Creating an A ppropriate Compensation Regime}

A number of issues arise in choosing the modalities of a compensation regime for resolving the M iddle East conflict. The principal issues include:

1. The group of claimants. The choices for appropriate claimant groups would include:

a. The 1948 property owners and their heirs, which would award those who suffered direct losses, but would disproportionally benefit land-owners, and disadvantage the poor and women (who frequently could not own or inherent property), ${ }^{134}$ as well as require personal documentary evidence which may not always exist;

b. The extended family or villages, which reflects the traditional rural social units and may resolve some problems surrounding claims over collective lands, but could create problems in determining membership, and would not address the landless or gender inequity issues;

c. Per capita awards for all the displaced, regardless of property ownership, which would address the inequality and gender issues, but would still require a determination of eligibility; or

d. A collective claim made on behalf of the displaced by the Palestinian state, which would create a national fund for future public works, but would not likely provide the kind of political and emotional closurefor the displaced that an individual compensation scheme should provide.

2. Formula. The choices among appropriate compensation formulas would include:

a. A claims-based system that bases compensation upon the value of the lost property, which would most directly link the financial remedies to theactual losses, but would also likely recreatetheinequalities of pre-1948 Palestinian society;

b. A modified claims-based system that creates several compensation categories based upon size of claim, which would be more efficient and award more progressive remedies than the pure claims-based system, but would also still be biased towards larger property owners;

c. A pure per capita payment system that would award equal payments to all refugees, thereby achieving efficiency and eliminating the social inequalities of the previous proposals, but would diminish thelink between payments and scale of losses; or

d. A modified per capita payment system that would create several categories of claimants based upon a generational or returnee v. non- returnee status, which would still be efficient and relative equitable, 
but which could also create social tension between the categories.

3. M echanism. What forms would compensation be awarded? Among the choices would be:

a. Cash payments, which are efficient to administer, but may not havesignificant macro-social or economic benefits;

b. Services or vouchers for individuals or families, which can be directed towards more focused public benefits plans, but are less flexible for the recipients and weaken the link between the compensation and actual losses;

c. Investment in community devel opment, which also promotes public ben efit plans, but weakens the link between the displaced and the purpose of the compensation; or

d. A equity scheme involving refugee ownership in collective development projects, which more directly connects the displaced to public plans, but does not strongly address the personal needs for closure.

4. Administrative Process. How should the compensation fund beadministered and distributed? Several politically feasible types of bodies are possible, including:

a. Palestinian state, which may build up the governing expertise of the future state, but which also raises issues of accountability and fairness;

b. A bilateral body made up of Palestine and Israel, which would involvethemain parties to the conflict, but would invite administrative gridlock because of their historical animosity;

c. A trilateral commission, involving Palestine, Israel and another party, which would lessen but not likely eliminatetheproblems of a bilateral commission; or

d. An international commission of parties acceptable to Palestine and I srael, or a U nited Nations commission, which would likely avoid gridlock, but would not be directly accountable to the direct stakeholders.

4. Compensation Determination. How should a global figure be determined? Among the approaches would include:

a. A politically determined number that is largely shaped through the course of the final status negotiations by theamount of money that the international community and Israel are willing to pay. While this is doubtlessly the easiest method to achieve a global figure, it would have little to do with the international legal obligation to provide fair compensation;

b. A macro-economic survey that would evaluate the assets as a prelude to determining an estimated value.
While this approach would approximate a fair value of the Palestinian losses, it also underestimates the degree of economic loss by minimizing the appre ciation of value over the years since dispossession, as well as downplaying moral losses; or

c. A multiplier approach, which would start with the estimated value and scale of the confiscated properties in 1948, and then add accepted appreciation factors to determine present-day value. This approach would come the closest to the "fair compensation" requirements, but, given the scale of Palestinian losses, it would doubtlessly be the most difficult method to fund.

At the unsuccessful Taba final status talks in January 2001, the Palestinian and Israeli negotiators agreed on several of the less contentious issues pertaining to compensation. ${ }^{135}$ Within the context of a comprehensive agreement, an International Commission and an International Fund would becreated to conclusively settleall outstanding compensation issues pertaining to Palestinian material and non-material losses. Also agreed upon would be a multitrack assessment system, where smaller claims below a certain monetary ceiling would be determined through a fast-track procedure. As well, Israel would accept some moral and financial responsibility for compensation, although no amount was seriously discussed. H owever, left unsettled by the time the Taba talks broke down was any agreement on the central questions of how the overall amount of compensation would be calculated, who would fund it, how the funds would be equitably distributed, and whether there would be separate parcels of funds for individual compensation and national projects.

\section{E. Who Should Pay?}

International law provides that thestate, body, or individual who causes the damage or harm in breach of an internationally recognized obligation is liable for the restitution and compensation. In this case, Israel would bear the primary responsibility for compensation, because it either created and perpetuated the Palestinian refugee problem in defiance of international law, or on the lesser ground that - regardless of moral blame - it has been unjustly enriched through its expropriation and use of Pal estinian properties, homes, and lands. Payments by Israel to meet its compensatory obligations could take the form of direct restitution (the return of homes and properties, which would likely lessen itspotential total liabilities), the handing over of the settlements, roads, and other structures built in the W est Bank and Gaza, and the financial contribution to a compensation fund. While I srael is an economically advanced nation - with a per capita income of over $\$ 18,000$ (U.S.), it is almost twenty times the 
level of the Palestinian economy - even its financial capacity is unlikely to entirely satisfy the requirements of a final compensation fund by itself. For a variety of complex realpolitik and practical reasons, the international community (primarily Europeand North America) would likely contribute to a compensation fund, which would enhance their voice in shaping the modalities of the compensation regime.

\section{Conclusion}

To satisfy the direction of the international community that the Palestinian refugee problem isto besettled in accordance with the principles of justice and equity, international law mandates that they are entitled to restitution and compensation for their losses. These losses attributable to Israel in violation of its international law obligations are substantial, and arise from: the expulsion or flight of over half of the Palestinian population; the confiscation of approximately 16,000 square kilometres of land, representing almost 80 per cent of $\mathrm{M}$ andate Palestine; the large-scale expropriation or destruction of Palestinian property; the refusal to allow the refugeesto return to their homes; the suffering caused by the losses and the decades in exile; and unjust enrichment from the use of theconfiscated properties. Although international law does not speak with precision regarding the formulas to be applied in such a large-scale and complex claim, it has clearly stipulated a number of principles that are directly applicable in any future final-status agreement between Palestine and Israel, including: (i) Restitution of the wrongly acquired property enjoys primacy, with compensation availablefor property damage and unjust enrichment; (ii) Compensation in place of restitution is acceptable, but only where restitution has become impossible for practical reasons; (iii) Compensation is availablefor both individual and community losses, and covers remedies for the loss or damage to immovableand movableproperty; for loss of actual income and future earning potential; for moral damages, including emotional harm; for unjust enrichment; for the costs of rehabilitation; and for an undertaking that such actions will not be repeated; (iv) however the legal formula for compensation has been phrased - be it "full," "fair," "adequate," etc. - it is to be given a sufficiently broad application so that the restorative purposes of human rights remedies are fulfilled; (v) The state actor that displaced the indigenouspopulation and unjustly ben efited from the confiscated properties is the party responsible for restitution and compensation; and (vi) The responsible state actor cannot argue that the difficulties of process - those caused by the passage of time, the magnitude of potential claimants, the determination of worthy claimants, the calculation of outstanding damages, the existence of subsequent domestic legislation that has transferred legal title, the hostile mood among the domestic political constituency, or the lack of a comprehensive settlement to the wider conflict - are justifiable barriers to satisfying an otherwise established claim for restitution and compensation.

The lessons of reconciliation in the modern world are profound. Those on both sides of an historical wound benefit immensely from a genuine effort to acknowledge, remember, and restore. While full justice may not have been achieved even in the template cases of post-war Europe or contemporary South Africa, the transformation of relations and the flourishing of new values among these former nemeses have been substantially aided by the restorative remedies of restitution and compensation. In the $\mathrm{M}$ iddle East, the closure of the decades-long conflict will requireno less. For Israelis, offering these remedies will finally allow a reckoning with the uncomfortable history that still stares out from among the ruined homes and wild olive groves that can be found in every corner of their country. For Palestinians, accepting the remedies of restitution and compensation will not return some past Eden, but it will address not only the sufferings they have endured and the material possessions they have lost, but also provide the tools for a productive national future. The requirements of an enduring regional peace require no less.

\section{Notes}

1. This essay uses theterm "displaced Palestinians" to includethe Palestinian refugees of the 1948 and 1967 wars and their descendants, as well as those Palestinians, whether refugees or not, who suffered compensable losses arising from the conflict in I srael/Palestine. WhilethePal estinian refugees will likely be the primary beneficiary of any compensation plan that emerges from a settlement of the M iddle East conflict, there are Palestinians who do not qualify as refugees within the applicable United Nations definition who nevertheless have claims for lost lands and properties that were expropriated by Israel at some point over the past five decades.

2. UNSC Res. 242, 22 November 1967: "The Security Council... affirms further the necessity... (b) for achieving a just settlement of the refugee problem."

3. Declaration of Principles on Interim Self-Government Arrangements, 13 September 1993, Government of Israel - Palestine Liberation Organization [1993] 33 I.L.M . 1525.

4. Treaty of Peace Between the State of Israel and the H ashemite Kingdom of Jordan, 26 October 1994, [1994] 34 ILM 43. See Article 8(2), where the parties commit to resolving the "massive human problems" of the refugees and displaced persons "in accordance with international law."

5. The centrepiece of the right to return is generally cited as Article 13(2) of the Universal Declaration of Human Rights, U.N. Doc. A/811: “Everyonehas theright to leaveany country, including his own, and to return to his country." On the 
application of the right to the Palestinian/I sraeli conflict, see J. Quigley, "Displaced Palestinians and a Right to Return" (1998) 39 Harvard International Law Journal 171; and K. Lawand, "The Right to Return of Palestinians under International Law" (1996) 8 International Journal of Refugee Law 533.

6. Thecurrent Pal estinian position is expressed in the Palestinian negotiating paper submitted during the final status talks with I srael at Taba, Egypt, in January 2001: "In accordance with the United Nations General Assembly Resolution 194 (III), all refugees who wish to return to their homes in Israel and live at peace with their neighbours havetheright to do so"; online: $<$ www.monde-diplomatique.fr/cahier/proche-orient/refuge espal -en> (date accessed: 18 December 2002).

7. Seethe "non-paper" produced by the European Union envoy M iguel Moratinos (the "M oratinos Document") which summarized the discussions between the Israeli and Palestinian delegations at the Taba talks in January 2001; online: <http://www.arts.mcgill.ca/M EPP/PRRN/papers/moratinos .html (date accessed: 18 December 2002). For a summation of the Israeli position on the right to return, see S. Gazit, The Palestinian Refugee Problem (Tel Aviv: Jaffee Center for Strategic Studies, 1995).

8. Gazit, ibid. at 27

9. Palestinian National Authority, Palestinian Refugees and the Right to Return (Jerusalem: M inistry of Information, 1995). Also see E. Zureik, Palestinian Refugees and the Peace Process (Washington, D.C.: Institute for Palestine Studies, 1996).

10. See "Private [Israeli] Response on Palestinian Refugees;" online: <http://www.monde-diplomatique.fr/cahier/procheorient/isra elrefugees-en $>$ (dateaccessed: 18 December 2002).

11. The Pal estinian negotiating paper issued at the Taba talks in January 2001 called for the restitution of real property, and compensation in today's values for loss of property, for moral suffering, and for rehabilitation. The paper maintained that: "The rights of return and compensation are independent and cumulative. A refugee's exercise of his or her right of return to Israel shall not prejudice his or her right to receive compensation [for loss of property], nor shall a refugee's receipt of compensation prejudice his or her right of return...." Supra note 6.

12. Supra note 7 .

13. J. Alpher \& K. Shikaki, The Palestinian Refugee Problem and the Right of Return (Cambridge, M ass.: W eatherhead Center for International Affairs, 1998).

14. A. Kubursi, "Palestinian Losses in 1948 in 1999 Dollars" (unpublished, 1999). For an overview of earlier cost estimates, see T. Rempel, "The Ottawa Process: Workshop on Compensation and Palestinian Refugees" (1999) 29 Journal of Palestine Studies 36.

15. For definitions of compensation and restitution, seeV. Condé, A $\mathrm{H}$ andbook of International H uman Rights Terminology (Lincoln: University of Nebraska Press, 1999). (Compensation: "M oney... paid... to extinguish a state's legal obligation by the payment of monetary damages to those whose human rights have been ... violated under international law"; Restitution: "A judicial remedy... to return property to another person from whom it was unlawfully taken or damaged.")

16. Other recent studies of the M iddle East final status negotiations on the Palestinian refugees emphasize the same point. For example, seethe 1998 report of theH arvard Joint W orking Group on I sraeli-Palestinian Relations: J. Alpher \& K. Shikaki, The Palestinian Refugee Problem, supra note 13.

17. Unless otherwise noted, this historical précis is drawn from thefollowing: W. Khalidi, ed., All That Remains (Washington, D.C.: Instituteof Pal estineStudies, 1992); B. M orris, Righteous Victims (New York: Knopf, 1999); B. M orris, The Birth of the Palestinian Refugee Problem, 1947-1949 (Cambridge: Cambridge University Press, 1987); I. Pappé, The Making of the Arab-Israeli Conflict, 1947-1951 (London: I.B. Tauris, 1992); and A. Shlaim, Thel ron Wall (N ew York: W .W . Norton \& Co., 1999).

18. The 1948 Palestinian refugee figures are highly contested. Official Israeli estimates place the number of refugees at 590,000 . Palestinian estimates range from 745,000 to 850,000 , while British and American estimates in the early 1950s put the number between 810,000 and 875,000 . The U nited $\mathrm{Na}$ tions adopted a figure of 726,000 in 1949 , and has commonly used figures in that vicinity since. For the purposes of this essay, I rely on the United Nations figure. See E. Zureik, Palestinian Refugees, supra note 9 at 17.

19. F. Bernadotte, "Progress Report of the U nited N ations M ediator on Palestine," UN GAOR, $3^{\text {rd }}$ sess., Supp. N o. 11, UN Doc. A/648, at 16.

20. Seein particular the writings of Israeli historian Benny M orris cited in note 16.

21. Bernadotte, supra, note 18 at 16 .

22. Ibid., at p. 20: "The right of innocent people, uprooted from their homes by the present terror and ravages of war, to return to their homes, should be affirmed and made effective, with assurance of adequate compensation for the property of those who may choose not to return."

23. UN GA Res. 181(II), 29 November 1947, Part I, C, chap. 2, para. 8.

24. Supra note 19 at 16 :

There have been numerous reports from reliable sources of large-scalelooting, pillaging and plundering, and of instances of destruction of villages without apparent military necessity. The liability of the Provisional Government of Israel to restore private property to itsA rab owners and to indemnify those owners for property wantonly destroyed is clear, irrespective of any indemnities which the Provisional Government may claim from the Arab States.

25. UN GA Res. 194 (III), 3 UN GAOR, pt. 1, Res. at 21, 24, UN Doc. A/810 (1948).

26. For a general history of the UNCCP, see: D. Forsythe, U nited N ations Peacekeeping: The Conciliation Commission for Palestine (Baltimore: Johns H opkins U niversity Press, 1972).

27. UNCCP, Historical Survey of Efforts of the United Nations Conciliation Commission for Palestine to Secure the Implemen- 
tation of Paragraph 11 of General Assembly Resolution 194 (III), A/AC.25/W.81/Rev.2, 2 October 1961, at para. 92. Also seeM . Fischbach, "TheU nited Nations and Palestinian Refugee Property Compensation" (2002) 31 J ournal of PalestineStudies 35.

28. Estimates of the number of Palestinian villages emptied between 1947-49 vary. See B. M orris, The Birth of the Palestinian Refugee Problem, supra note 17 at 297-98, who suggests 370; W. Khalidi, ed., All That Remains, supra note 17, who estimates the number to be 418; and I. Pappé, The M aking of the ArabIsraeli Conflict, supra note 17, who offers a figure of 400.

29. D. Peretz, Palestinian Refugee Compensation (Washington, D.C.: Center for Policy Analysis on Palestine, 1995) at 12-13.

30. D. Peretz, Palestinians Refugees and the Middle East Peace Process (Washington, D.C.: U.S. Institute for Peace, 1993) at 87.

31. D. Peretz, Palestinian Refugee Compensation, supra note 29 at 13. Also see F. Lewis, "Agricultural Property and the 1948 Palestinian Refugees: Assessing the Loss" (1996) 33 Explorations in Economic H istory 169.

32. D. Artz, Refugees into Citizens: Palestinians and the End of the Arab-I sraeli Conflict (N ew York: Council of Foreign Relations, 1997), at p. 16.

33. I. Kershner, "TheRefugeePriceTag" The erusalem Report (17 July 2000) 22-23.

34. Ibid. at 23. Also see Rempel, supra note 14.

35. E. Benvenisti \& E. Zamir, "Private Claims to Property Rights in theFuture I sraeli-Palestinian Settlement" (1995) 89 American Journal of International Law 295. Also see T. Rempel, "Dispossession and Restitution" in S. Tamari, ed., Jerusalem 1948 (J erusalem: Institute of Jerusalem Studies, 1999) 189.

36. Peretz, Palestinian Refugee Compensation, supra note 29 at 7; Artz, supra note 32 at 16; also seeD. Kretzmer, The Legal Status of the Arabsin Israel (Boulder: Westview Press, 1990), ch. 4.

37. B. Morris, The Birth of the Pal estinian Refugee Problem, supra note 17 at 155, states that these developments included:

... the gradual destruction of the abandoned Arab villages, the cultivation and/or destruction of Arab fields and the share-out of the Arab lands to Jewish settlements, the establishment of new settlements on abandoned lands and sites and the settlements of Jewish immigrants in empty Arab housing in the countryside and in urban neighbourhoods. Taken together, they assured that the refugees would have nowhere, and nothing, to return to.

38. The principal Israeli pre-conditions, as summarized in the mediation conferences organized between 1949 and 1952 by the UNCCP, were: (i) compensation must be part of a general peacesettlement; (ii) therewould beno restitution of property; (iii) compensation would not be paid for individual claimants, but only to a collective fund, which would be utilized for the resettlement of the refugees el sewhere; (iv) Israel would maintain the right to raise its own claims for property damages and losses; (v) its contributions to a compensation fund would be limited by its ability to pay; (vi) it accepted no moral or political responsibility for thecreation of the refugee problem; and (vii) the resolution of abandoned Jewish property claims in Iraq, and, subsequently, to Jewish property left behind in other Arab countries. See UNCCP, supra note 27 at paras. 62-65, 72-75, 99-101; Peretz, Palestinian Refugee Compensation, supra note 29 at 10-11; R. Zweig, "Restitution of Property and Refugee Rehabilitation: Two Case Studies" (1993) 6 Journal of Refugee Studies 56.

39. In March 1951, M oshe Sharett, the Israeli Foreign M inister, told the Knesset that:

We... have an account with the Arab world - namely, the account of the compensation that accrues to the Arabs who left the territory of Israel and abandoned their property... The act now committed by the Kingdom of Iraq... forces us to link the two accounts... We will take into account the value of the Jewish property that has been frozen in Iraq with respect to the compensation we have undertaken to pay the Arabs who abandoned property in Israel.

Quoted in Yehouda Shenhav, "The J ews of I raq, Zionist I deology, and the Property of the Palestinian Refugees of 1948: An Anomaly of National Accounting" (1999) 31 International Journal of Middle East Studies 605 at 619.

40. At the UNCCP conferences, the position of the Arab states focused on thefollowing: (i) the Palestinian refugees had to be given a free choice about returning to their homes, and only then could compensation be determined as between those returning and those resettling elsewhere; (ii) compensation was to be paid to individual claimants; (iii) compensation should reflect the true value of the property; (iv) Israel bore the principal responsibility for paying the compensation, and if it is unable to pay the full amount, the United Nations also boreresponsibility because of itsrolein the 1948 partition; and (v) the refugees must be represented at the different stages of negotiations. UNCCP, supra note 27 at paras. 102-5.

41. E. Buehrig, The UN and the Palestinian Refugees (Bloomington: Indiana U niversity Press, 1971) 21-25.

42. The United States Assistant Secretary of State, George $M$ cGhee, presciently foresaw the consequences of leaving the Palestinian issue unresolved, during testimony given to the H ouse Committee of Foreign Affairs in February 1950:

The presence of three-quarters of a million idle, destitute people - a number greater than the combined strength of all the standing armies of the N ear East - whose discontent increases with the passage of time, is the greatest threat to the security of the area which now exists.

U.S. Congress, House, Committee on Foreign Affairs, Hearings on Palestine Refugees, $81^{\text {st }}$ Cong., $2^{\text {nd }}$ Sess. S. J. Res. 153, 16-17 February 1950 (Washington, D.C.: USG PO, 1950) 9.

43. Theaccepted starting point for the sources of international law is Article 38(1) of the Statute of the International Court of Justice. It directs the Court to apply: (i) international conventions, whether general or particular; (ii) international customary law; (iii) general principles of law, which include principles commonly accepted by various domestic legal systems, and principles of equity; (iv) judicial decisions; and (v) 
scholarly views. Other accepted sources of international law includethefrequent restatement of principles by international organizations, particularly by theU nited N ations. SeegeneralIy I. Brownlie, Principles of Public International Law, $5^{\text {th }}$ ed. (Oxford: Oxford University Press, 1998) 1-30.

44. A. de Zayas, "Population, Expulsion and Transfer" in R. Bernhardt, ed., 8 Encyclopaedia of Public International Law (Amsterdam: N orth H olland Publishing Co., 1992) 438 at 443. ("As a fundamental denial of the right to self-determination and in the light of the Nuremberg principles, the Genocide Convention and the developing body of human rights law, population expulsion must be seen as incompatible with modern international law.")

45. International Law Association, Declaration of Principles of International Law on Compensation to Refugees, Cairo, April 1992. Reprinted in (1993) 6 Journal of Refugee Studies 69. Also seeH . Garry, "TheRight to Compensation and RefugeeFlows: A 'Preventative M echanism' in International Law?' (1998) 10 International Journal of Refugee Law 97; L. Lee, "The Right to Compensation: Refugees and Countries of Asylum" (1986) 80 American Journal of International Law 532.

46. International Law Association, ibid. Principle 1 states:

The responsibility for caring for the world's refugees rests ultimately upon the countries that directly or indirectly force their own citizens to flee and/or remain abroad as refugees. The discharge of such responsibility by countries of asylum, international organizations (e.g., UNHCR, UNRWA, IOM ) and donors (both governmental and nongovernmental), pending the return of refugees, their settlement in place, or their resettlement in third countries, shall not relieve the countries of origin of their basic responsibility, including that of paying adequate compensation to refugees.

47. Such a principle has been a policy centrepiece for organizations dedicated to the material restitution of human rights victims. For example, a founding principle of the Jewish Restitution Successor Organization, which played a significant role in the recovery of heirless property owned by Jewish victims of the H olocaust, stated: "that a nation may not retain property that it gained by the mass spoliation of minorities whom it persecuted on racial or religious grounds." See $\mathrm{S}$. Kagan \& E. W eismann, Report on the 0 perations of the J ewish Restitution Successor Organization, 1947-1972 (New York: J.R.S.O., 1972) at 6.

48. While serious violations of human rights such as mass population displacements are, at one level, irreparable, since no remedy can perfectly restore the victim to her or his position prior to the violation, the U nited Nations Special Rapporteur for Human Rights has nonetheless argued that "reparation for human rights violations has the purpose of relieving the suffering of, and affording justice to, victims by removing to the extent possible the consequences of the wrongful acts." T. van Boven, Special Rapporteur, Study Concerning the Right to Restitution, Compensation and Rehabilitation for Victims of Gross
Violations of H uman Rights and Fundamental Freedoms, UN Doc. E/CN.4/Sub.2/1993/8 (2 July 1993) at para. 137.

49. L. Lee, "The Right to Compensation," supra note 45.

50. E. M arx, "Refugee Compensation" in J. Ginat \& E. Perkins, eds., Palestinian Refugees: Old Problems- N ew Solutions (Norman: University of O klahoma Press, 2001).

51. 19 N ovember 1794,8 Stat. 116.

52. Ibid., Article 9: "It is agreed, that British Subjects who now hold lands in the Territories of the U nited States... shall continueto hold them according to thenatureand Tenure of their respective Estates and Titles therein, and may grant Sell or Devise the same to whom they please, in likemanner as if they were Natives..."

53. K. Schwerin, "German Compensation for Victims of Nazi Persecution" (1972) 67 Northwestern University Law Review 479.

54. U nited N ations, "H istorical Precedents for Restitution of Property or Payment of Compensation to Refugees," UN Doc. A/AC.25/W.81/Rev.2, M arch 1950.

55. Ibid.

56. For other historical examples besides the treaties mentioned, see K. Schwerin, supra note 53.

57. Fourth Geneva Convention of 1949,75 U.N.T.S. 287 , Article 49 ("Individual or mass forcibletransfers, as well as deportations of protected persons from occupied territory to the territory of the Occupying Power or to that of any other country, occupied or not, are prohibited, regardless of their motive.")

58. Convention Respecting Reciprocal Emigration, 27 November 1919, 1 LNTS 68.

59. Convention Respecting the Exchange of Populations, 30 July 1923, 2 The Treaties of Peace, 1919-1923 653 (New York: Carnegie Endowment for International Peace, 1924).

60. (Merits) 1928 P.C.I.J. (Ser. A.), N o. 17.

61. Ibid. at 29 .

62. Ibid. at 47.

63. Reparations for I njuries Suffered in the Service of the U nited Nations, Advisory Opinion, I.C.J. Reports 1949, 184.

64. Valesquez Rodriquez Case (Compensatory Damages), (1989), 7 Inter-Am. Ct. H.R. (ser. C).

65. T. van Boven, Preliminary Report, Study Concerning the Right to Restitution, Compensation and Rehabilitation for Victims of Gross Violations of Human Rights and Fundamental Freedoms, U.N. Doc. E/CN.4/Sub.2/1990/10 (26 July 1990).

66. E. Rosand, "TheRight to Compensation in Bosnia: An Unfulfilled Promise and a Challenge to International Law" (2000) 33 Cornell International Law Journal 113; H . Garry, "The Right to Compensation and Refugee Flows," supra note 45; L. Lee, "The Preventative A pproach to the Refugee Problem" (1992) 28 Willamette Law Review 811; L. Lee, "'The Right to Compensation," supra note 45.

67. Lee, "The Preventative Approach," ibid. at 829.

68. Lee, "The Right to Compensation," supra note 45 at 544.

69. For a comprehensive collection of therel evant $U N$ resolutions on the M iddle East conflict, see the five-volume series: United Nations Resolutions on Palestine and the Arab-I sraeli Conflict 
(W ashington, D.C.: Institutefor Pal estineStudies, 1975, 1988 1988, 1993, 1999).

70. Ibid., vol. 5, 211-12.

71. B. Sloan, "General Assembly Resolutions Revisited (Forty Years After)" (1987) 58 British Yearbook of International Law 39; J. Castaneda, Legal Effects of U nited N ations Resolutions (N ew York: Columbia University Press, 1969); S. Bleicher, "The Legal Significance of Re-Citation of General Assembly Resolutions" (1969) 63 American J ournal of International Law 444; R. Falk, "On the Quasi-Legislative Competence of the General Assembly" (1966) 60 American Journal of International Law 782; R. Higgins, "The Development of International Law through the Political Organs of the United Nations" in Proceedings of the $59^{\text {th }}$ Annual M eeting of the American Society of International Law 116.

72. See in particular the oft-cited dissenting opinion of Judge Tanaka in the South West Africa Cases (Second Phase), 1966 ("What is required for customary international law is the repetition of the same practice; accordingly, in this case resolutions, declarations, etc., on the same matter in the same, or diverse, organizations must take place repeatedly."), reproduced in I. Brownlie, ed., Basic Documents on H uman Rights, $3^{\text {rd }}$ ed. (Oxford: Clarendon Press, 1992) at 575. Also see M ilitary and Paramilitary Activities In and Against Nicaragua [1986] I.C.J. Rep. 99-100; Namibia Advisory Opinion, [1971] I.C.J. Rep. 50.

73. Statute of the International Court, Art 38(1)(c).

74. The Roman lawyer and legislator Pomponius stated in the second century A.D. that: "For this by nature is equitable, that no one be made richer through another's loss."; quoted in J.P. Dowson, U njust Enrichment: A Comparative Analysis (Boston: Little, Brown and Co., 1951), at 3.

75. [1943] A.C. 32, at 61. In the Third World, a similar view was stated by M r. J ustice Guha Roy of I ndia in 1961: "That a wrong done to an individual must be redressed by the offender himself or by someone else against whom the sanction of the community may bedirected is one of those timeless axioms of justice without which social lifeis unthinkable." "Isthe Law of Responsibility of States for Injuries to Aliens a Part of Universal International Law?" (1961) 55 American Journal of International Law 863.

76. American Law Institute, Restatement of the Law of Restitution, Quasi-Contract and Constructive Trusts (St. Paul: American Law Institute Publishers, 1937) at 12.

77. T. van Boven, Revised Set of Basic Principles and Guidelines on theRight to Reparation for Victims of GrossV iolations of H uman Rights and Humanitarian Law, U.N. Doc. E/CN.4/Sub.2/ 1996/17, 24 M ay 1996. Also see: (Third) Restatement of the Law, 901 (Redress for Breach of International Law).

78. Supra note 5.

79. Art. 2(3)(a), G.A. Res. 2200A (XXI), 21 U.N. GAOR Supp. (No. 16) at 52.

80. Art. 6, G.A. Res. 2106 (XX), B, 20 U.N. GAOR.

81. Art. 10, O.A.S., Treaty Series N o. 36, 1144 U.N.T.S. 123.

82. Art. 21(2), ibid.
83. Art. 21(2), O.A.U. Doc. CAB/LEG/67/3 rev.5.

84. Supra note 79 at Article 9(5).

85. Article 5(5), E.T.S. N o. 5, Rome, 4.XI. 1950.

86. Article 75, [1998] 37 I.L.M. 999.

87. Convention against Torture and $\mathrm{O}$ ther Cruel, Inhuman or De grading Treatment or Punishment, G.A. Res. 39/46, Annex, 39 UN GAOR Supp. N 0. 51 at 97, art. 14(1) ("an enforceableright to fair and adequate compensation, including the means for as full rehabilitation as possible"); D eclaration on theProtection of All Persons from Enforced Disappearance, G.A. Res. 47/133, 47U N GAOR, Supp. N o. 49 at 207, art. 19 ("the victims of acts of enforced disappearance and their families shall obtain redress and have the right to adequate compensation, including the means for as complete a rehabilitation as possible"); Convention Concerning Indigenous and Tribal Peoples in Independent Countries (I.L.O. N o. 169), 72 I.L.O. Official Bull. 59, Article 16(5) ("full compensation for any loss or injury").

88. Supra note 48.

89. Ibid. at para. 45.

90. Ibid. at para. 131.

91. Ibid. at para. 137

92. Ibid. at para. 137

93. Ibid. at para. 135 .

94. Velasquez-Rodriguez v. Honduras (Compensatory Damages) (1989), 7 Inter-Am C.H.R. (ser. C), at para. 25. Also see D. Shelton, Remedies in International Human Rights Law (Oxford: Oxford University Press, 1999), ch. 8. The UNCHR Special Rapporteur (van Boven) study, ibid. notes, at para. 81, that the European Court had, by 1993, awarded "just satisfaction" of a pecuniary nature in far over one hundred cases.

95. (M erits) (1988), 4 Inter-Am Ct.H.R. (ser. C); (Compensatory Damages), (1989), ibid; (Interpretation of the Judgement on Compensatory Damages) (1990), 9 Inter-Am Ct.H .R. (ser. C).

96. Supra note 81.

97. (Merits), supra note 95 at para. 26: "Reparation for harm brought about by the violation of an international obligation consists in full restitution (restitutio in integrum), which includes the restoration of the prior situation, the reparation of the consequences of the violence, and indemnification for patrimonial and non-patrimonial damages, including emotional harm."

98. (Interpretation of the Judgement on Compensatory Damages), supra note 95 at para. 27.

99. See D. Shelton, "Reparations in the Inter-American System" in D. Harris \& S. Livingstone, The Inter-A merican System of Human Rights (Oxford: Clarendon Press, 1998), ch. 6.

100. Supra note 85 , Article 8 states that: "Everyone has the right to respect for... his home."

101. (1997), 23 E.H.R.R. 513 (E.C.H.R.).

102 (1998), 26 E.H.R.R. C.D.5 (E.C.H.R.).

103. Cyprus v. Turkey (Application 25781/94) (8 September 1999).

104. I bid. at para. 321.

105. J. Mickletz, "An Analysis of the $\$ 1.25$ Billion Settlement Between the Swiss Banks and H olocaust Survivors and H o- 
locaust Victims' Heirs" (1999) 18 Dickinson Journal of International Law 199; S. Denburg, "Reclaiming Their Past: A Survey of Jewish Efforts to Restitute European Property" (1998) 18 Boston College Third World Law Journal 233; R. Zweig, German Reparations and the Jewish W orld: A History of theClaims Conference(Boulder: W estview Press, 1987); K. Schwerin, supra note 52; N. Balabkins, W est Germany Reparations to Israel (New Brunswick, N.J.: Rutgers University Press, 1971).

106. [1953] BGB1. II 35. See generally Schwerin, supra note 53 .

107. According to Balabkins, supra note 105 at 153 , the primary German legislation, theF ederal Indemnification Law of 1953, provided for "compensation for loss of life, damages to body and health, including medical costs, reduction of income, loss of freedom, incarceration, arrest, property losses, capital losses, discriminatory taxes, impairment of economic and professional advancement, etc."

108. Conference on Jewish Material Claims against Germany, Restitution Guide, online: <http://www.claimscon.org/ CC_content.html> (dateaccessed: 26 N ovember 2000). Also see the testimony of U.S. D eputy Treasury Secretary Stuart Eizenstat to the U.S. Senate Foreign Relations Committee, 5 April 2000, online: <http://www.usis.it/wireless/wfa00405/ A 0040508.htm > (date accessed: 26 N ovember 2000).

109. Restitution Guide, ibid.

110. I. Pogany, Righting W rongs in Eastern Europe ( $M$ anchester: M anchester University Press, 1997); M . Henry, The Restitution of Jewish Property in Central and Eastern Europe (N ew York: American Jewish Committee, 1997).

111. Restitution Guide, supra note 108.

112. The General Framework Agreement for Peace in Bosnia and Herzegovina (1996), 35 I.L.M. 1171.

113. Ibid., Annex 7, Articlel: “All refugees and displaced persons have the right freely to return to their homes of origin. They shall have the right to have restored to them property of which they were deprived in the course of hostilities since 1991 and to be compensated for any property that cannot be restored to them." Further, Article XII(5) permits all refugees and displaced persons the choice between return and compensation, and ensures that the owner has the right to compensation in lieu of return.

114. Ibid., Annex 7, ArticleXI.

115. E. Rosand, supra note 66; M. Cox, "The Right to Return Home: International Intervention and Ethnic Cleansing in Bosnia and Herzegovina" (1998) 47 International and Comparative Law Quarterly 599.

116. "Kevesevic V. Federation of Bosnia and Herzegovina" (1998) 20 Human RightsLaw Journal 318; (1999) 20 Human Rights Law Journal 326.

117. R. Lillich, ed., The U nited Nations Compensation Commission (Irvington: Transitional Publishers Inc., 1995); D. Be terman, "The United Nations Compensation Commission and the Tradition of International Claims Settlement" (1994) 17 New York University Journal of International Law and Politics 1 .
118. N. Wuehler, "The Iran-U nited States Claims Tribunal: Ten Years of Arbitration at W ork" (1991) 8 J ournal of International Arbitration 5; W. M app, I ran-US Claims Tribunal (M anchester: M anchester University Press, 1990).

119. A. Painter, "Property Rights of Returning Displaced Persons: The Guatemalan Experience" (1996) 9 Harvard Human Rights Journal 145.

120. The Civil Liberties Act of 1988, 50 U.S.C. app. 1989 (b)-4; which authorized payments of $\$ 20,000$ (US) to each person who suffered as a consequence. Also seeE. Yamamoto, "Racial Reparations: Japanese American Redress and African American Claims" (1998) 40 Boston College Law Review 477.

121. M. O matsu, Bittersweet Passage: Redress and the Japanese Canadian Experience (Toronto: Between The Lines, 1992).

122. N. N ewton, "Compensation, Reparations, and Restitution: Indian Property Claims in the United States" (1994) 28 Georgia Law Review 453; M. Ferch, "Indian Land Rights: An International Approach to Just Compensation" (1992) 2 Transitional Law and Contemporary Problems" 301.

123. W. Henderson \& D. Ground, "Survey of Aboriginal Land Claims" (1994) 26 Ottawa Law Review 187; K. Coates, ed., Aboriginal Land Claims in Canada (Toronto: Copp Clark Pitman Ltd., 1992).

124. R. Bartlett, "The Landmark Case on Aboriginal Title in Australia: M abo v. State of Queensland" in S. Corrigan \& J. Sawchuk, eds., The Recognition of Aboriginal Rights (Brandon: Bearpaw, 1996) 132.

125. B. Gilling, "The Maori Land Court in New Zealand: An H istorical Overview" in S. Corrigan \& J. Sawchuk, eds., The Recognition of A boriginal Rights, ibid., 121.

126. See generally N. Kritz, ed., Transitional Justice: H ow Emerging Democracies Reckon with Former Regimes (Washington, D.C.: U.S. Institute of Peace Press, 1995).

127. This part of the essay draws from the papers presented at a workshop held in Ottawa, Canada, in July 1999 on the role of compensation as part of a comprehensive solution to the Palestinian refugee issue. For a further review of the shape of theseworkshop discussions, see "Final Report, W orkshop on Compensation," online: <http://www.arts.mcgill.ca/M EPP/ PrrN/prcomp3.html> (date accessed: 18 December 2002); and T. Rempel, "The Ottawa Process," supra note 14.

128. Supra note 5 . It is probable that the right to return had al ready achieved customary status in international law by the time the Universal Dedaration was declared. See G. Boling, "Palestinian Refugees and the Right to Return: An International Law Analysis," BADI L Brief N o. 8 (Bethlehem: January 2001).

129. United Nations Human Rights Committee, General Comment \#27: Freedom of M ovement: Article 12, 2 November 1999, CCPR/C/21/Rev.1/Add.9, para. 21. In para. 19, the Committee states: "The right to return is of utmost importance for refugees seeking voluntary repatriation. It also implies prohibition of enforced population transfersor mass expulsions to other countries." 
130. For an articulation of the right in the context of the M iddle East, see Human Rights Watch, "Letter to Israeli Prime Minister Ehud Barak," 22 December 2000, online <http://www. hrw.org/press/2000/12/isrpab1222.htm> (date accessed: 18 January 2001): "As in the cases of all displaced people, those unable to return to a former home because it is occupied or has been destroyed, or those have lost property, are entitled to compensation. However, compensation is not a substitute for the right to return to the vicinity of a former home, should that be one's choice."

131. BADIL Resource Centre for Palestinian Residency and Refugee Rights, "The Impact of Return on Compensation", paper presented to the July 1999 Ottawa W orkshop on Compensation.

132. Ha'aretz, 21 September 2000.

133. The M oratinos Document, supra note 7, stated that: "The Palestinian side raised the issue of restitution of refugee property. The Israeli side rejected this."

134. For a thoughtful discussion of theissue of compensation and Palestinian women, see N. Abdo, "Engendering Compensation: Making Refugee Women Count!" (M arch 2000), online: <http://www.arts.mcgill.ca/M EPP/PRRN/abdo.html> (date accessed: 18 December 2002).

135. See the M oratinos D ocument, supra note 7.

M ichael Lynk teaches at the Faculty of Law, the U niversity of W estern O ntario, London, O ntario, Canada. Prior to teaching, he practised law in Ottawa, and in 1989, served as a refugee affairs officer with the United $\mathrm{N}$ ations Relief and W orks Agency on the W est Bank. Prof. Lynk would liketo thank Jill T ansley for her invaluable assistance, advice and encouragement during the writing of this paper, Lance Ceaser for his deft research, and the Law Foundation of $O$ ntario for itsfinancial assistanceduring the research stage. For spacepurposes, this articlehas used shortened footnotes. The full text version of endnotes is to be published in the online version of this paper available on the Refuge web site: <www.yorku. ca/crs/refuges. 